\title{
An Analysis of Lesson Plan Preparation through Google Classroom in Junior High School
}

\section{Ni Nyoman Diah Krisna Larasati ${ }^{*}$, Dewa Komang Tantra ${ }^{2}$, Luh Gd Rahayu} Budiarta $^{3}$

1,2,3 Pendidikan Bahasa Inggris, Universitas Pendidikan Ganesha, Singaraja, Indonesia

\section{ART I CLE IN F O}

Article history:

Received February 08, 2021

Revised February 10, 2021

Accepted March 23, 2021

Available online April 25, 2021

Kata Kunci:

RPP, Google Classroom

Keywords:

Lesson Plan, Google Classroom

\section{A B S T RAK}

Perencanaan pembelajaran memerlukan persiapan dan pemilihan tujuan pembelajaran, materi, media dan sumber belajar, kegiatan pembelajaran, dan instrumen penilaian. Penyusunan RPP pada pembelajaran online melalui penggunaan google classroom merupakan hal baru bagi para guru karena guru belum memiliki pengalaman dalam melakukan penyusunan RPP pembelajaran online. Tujuan penelitian ini adalah menganalisis penyusunan RPP melalui google classroom berbasis pendekatan saintifik pada kurikulum K-13. Penelitian ini menggunakan desain penelitian kualitatif, dengan angket yang digunakan sebagai instrumen yang memuat aspek-aspek diantaranya tujuan pembelajaran, materi pembelajaran, kegiatan pembelajaran, media dan sumber pembelajaran, dan penilaian pembelajaran. Subjek penelitian dalam penelitian ini adalah seorang guru bahasa Inggris. Hasil penelitian menemukan bahwa RPP yang dikembangkan guru berkembang dengan baik, karena RPP juga memenuhi 5 aspek RPP yang lengkap. Berdasarkan hasil penelitian dapat disimpulkan bahwa RPP yang dikembangkan dapat diterapkan dalam pembelajaran online karena guru telah melengkapi aspek RPP Kurikulum 2013, dan menggunakan google classroom sebagai platform yang sesuai dalam pembelajaran online.

\section{A B S T R A C T}

Learning planning requires the preparation and selection of learning objectives, learning media and resources, learning activities, and assessment instruments. The preparation of lesson plans for online learning through the use of google classroom is a new thing for teachers because teachers do not have experience in preparing online learning lesson plans. The purpose of this study was to analyze the preparation of lesson plans through google classroom based on a scientific approach to the K-13 curriculum. This study uses a qualitative research design, with the device used as an instrument covering aspects that include learning objectives, learning materials, learning activities, media, and learning resources, and learning benefits. The research subject in this study was an English teacher. The results of the study found that the RPP developed by teacher-developed well because the RPP also fulfilled 5 aspects of a complete RPP. Based on the results of the study, it can be said that the RPP developed can be applied in online learning, it has completed the 2013 Curriculum RPP material, and uses Google Classroom as an appropriate platform for online learning.

\section{Introduction}

The Covid-19 pandemic has become a multidimensional problem facing the world, its impact is also felt in the education sector which causes all learning processes and learning activities to be carried out at home. The learning system is replaced with online learning so that the learning process continues. This changes the pattern of learning that requires teachers and education developers to provide learning materials and teach students directly through remote digital tools, one of which is the preparation of Learning Implementation Plans (RPP). The learning implementation plan serves as a reference for carrying out the teaching and learning process in the classroom to be more effective and efficient (Antara \& Renda, 2016; Rahardjo, 2016; Suciati \& Astuti, 2019; Sulistyowati, 2014).

The preparation of lesson plans in learning is very important, because in principle learning is an interaction between teachers and students, to create student learning experiences such as reading, listening, studying, analyzing, doing things, and various other forms of activities. Thus, the existence of 
RPP is expected to facilitate, improve, streamline, and optimize the quality of the learning process to achieve learning objectives. The existence of lesson plans is one of the benchmarks for a teacher's pedagogic competence. Pedagogic competence is the ability to manage student learning, which at least includes understanding educational insights and foundations, curriculum/syllabus development, utilization of learning technology, student understanding, learning planning, educational and dialogical learning implementation, evaluation of learning processes and outcomes, and development of students to actualize the various potentials (Alamsyah et al., 2018; Ali, 2018; Damsik, 2017). The preparation of online learning lesson plans through the use of Google Classroom is a new experience for teachers. Related to this, the knowledge and ability of teachers in utilizing online platforms are also very much needed. Thus, teachers are required to maximize the five aspects of lesson plans in online learning.

Based on the observations that have been made, SMPN 1 Abang was chosen as the object of research because it has used google classroom as the main platform for online learning in Abang district, the use of google classroom at SMPN 1 Abang district as the main platform to support online teaching and learning activities. In addition, this school has also implemented the K-13 curriculum with a scientific approach in its learning activities. The scientific approach helps teachers to develop learning activities by separating the process into several detailed steps. Because this study focuses on the preparation of lesson plans based on a scientific approach in the K-13 curriculum, it is necessary to select schools that have implemented this curriculum.

Google Classroom is an online education platform that allows teachers to upload materials such as images, videos, and links, invite students to join online classes, perform student assignments and quizzes, and manage student assessments. The advantages provided are that online learning activities are carried out quickly and easily, flexible, centralized data storage, and also guaranteed safety and security. Moreover, the platform can be accessed easily by using one Gmail account which makes it easy and convenient. Due dates, comments, and assessments of student assignments are also provided so that teachers can monitor the learning process. there are not many in-depth studies regarding the analysis of the preparation of online lesson plans through google classroom based on a scientific approach to English subjects in junior high school.

Several studies that are relevant to this research such as research conducted by (Kurniawati et al., 2019) found that the learning process using google classroom was in the very good category, student learning outcomes were in the moderate category, there were differences in learning outcomes between male and female students, and student responses were in the very high category. Then the research conducted by (Fauziah et al., 2019) found that google classroom training for teachers in junior high schools in Subang provided tremendous benefits for teachers. Other research was also conducted and found that the use of google classroom in cooperative learning strategies was also assessed as being able to foster activeness, the ability to think, enthusiasm and interest of students, because with the appropriate media and learning strategies, the learning process is no longer boring (Wicaksono, 2020). The purpose of this study was to analyze the preparation of lesson plans through Google Classroom based on a scientific approach to the K-13 curriculum.

\section{Method}

This study uses a qualitative design as a research design. The research subject in this study was an English teacher at SMP N 1 Abang Karangasem because the teacher had compiled online learning lesson plans through google classroom since online learning was implemented. The instrument on preparing lesson plans was adopted from the guideline on lesson plans from LPPL which was also supported by the study (Bin-Hady \& Abdulsafi, 2019). Then the instrument is adjusted to the use of google classroom for online learning. This instrument is identified through the following aspects: 1) learning objectives, 2) learning materials, 3) learning activities, 4) learning media and resources, and 5) learning assessment. Concerning instrument validity, experts are required to check the feasibility of the instrument. The crosstabulation table was used to place the examination results between the two experts.

\section{Results and Discussion}

There are four lesson plans on different topics, namely: (1) congratulation, (2) intention, (3) label, and (4) procedure text. The RPP is based on the five aspects proposed by LPPL (2007) which are supported by studies from (Bin-Hady \& Abdulsafi, 2019). Thus, the explanation of the RPP is explained as follows.

The first step taken by the English teacher in preparing the lesson plans is to state the learning objectives. Learning objectives are statements that define the expected goals of learning English in Junior High School (Fitriyanti, 2019; Istiqomah, 2018). Learning objectives contain behaviors that can be 
observed or measured. In the 2013 Curriculum guidelines, learning objectives must contain four parts, namely audience (A), behavior (B), condition (C), and degree of achievement (D).(Astria, 2013; Maba, 2017; Oktafianti, 2019). The teacher explained the learning objectives completed with the four previously mentioned elements. The following statement shows that the English teacher has explained the learning objectives related to the guidelines. The learning objectives in the lesson plan can be seen in Table 1.

Table 1. The Learning Objectives In The Lesson Plan

\begin{tabular}{|c|c|c|c|}
\hline $\begin{array}{l}\text { Lesson Plan } 3.1 \\
\text { (Congratulation) }\end{array}$ & $\begin{array}{c}\text { Lesson Plan } 3.2 \\
\text { (Intention) }\end{array}$ & $\begin{array}{c}\text { Lesson Plan } 3.3 \\
\text { (Label) }\end{array}$ & $\begin{array}{c}\text { Lesson Plan } 3.4 \\
\text { (Procedure Text) }\end{array}$ \\
\hline $\begin{array}{l}\text { The students (A) are able } \\
\text { to identify and to create } \\
\text { (B) the congratulatory } \\
\text { expressions (C) based on } \\
\text { social functions, text } \\
\text { structure and linguistics } \\
\text { elements in } \\
\text { congratulations (D). }\end{array}$ & $\begin{array}{l}\text { The students (A) are } \\
\text { able to apply (B) the } \\
\text { expressions of } \\
\text { intention of doing } \\
\text { something (C) based } \\
\text { on social functions, } \\
\text { text structure and } \\
\text { linguics elements in } \\
\text { oral and written form } \\
\text { (D). }\end{array}$ & $\begin{array}{l}\text { The students (A) are } \\
\text { able to identify, to } \\
\text { compare, and to } \\
\text { provide brief } \\
\text { explanations (B) } \\
\text { general information } \\
\text { from variety of images } \\
\text { (C) using the correct } \\
\text { language, politely with } \\
\text { full responsibility (D). }\end{array}$ & $\begin{array}{l}\text { The students (A) are } \\
\text { able to identify, to } \\
\text { modify, and to provide } \\
\text { (B) brief explanations of } \\
\text { text structures and } \\
\text { imperative sentences } \\
\text { (C) using the correct } \\
\text { language, discipline, } \\
\text { cooperation and } \\
\text { responsibility (D). }\end{array}$ \\
\hline
\end{tabular}

In addition to stating the learning objectives, English teachers were asked to explain whether they chose the learning objectives according to the core and basic competencies. In this regard, the productive goals accepted by the teacher are based on the four parts of the learning objectives. In addition, the learning objectives chosen by the teacher are specifically for teaching English, because they are related to learning targets and can be carried out by the teacher in carrying out the teaching and learning process. Meanwhile, competence is an essential attitude, knowledge, and skill in learning English at SMP N 1 Abang. In the example, the English teacher has linked learning objectives with knowledge (nouns), skills (to identify, apply, compare, provide, and modify), and attitudes (correct language, discipline, cooperation, and responsibility). The second step taken by the English teacher is to organize, compile, and develop teaching materials or teaching materials. In terms of learning materials for each topic, the teacher focuses on the topic of each lesson plan. The learning materials prepared in the lesson plans can be seen in Table 2 .

Table 2. Learning Materials Prepared by Teachers in Compiling RPP

\begin{tabular}{|c|c|c|c|}
\hline $\begin{array}{c}\text { Lesson Plan 3.1 } \\
\text { (Congratulation) }\end{array}$ & $\begin{array}{c}\text { Lesson Plan } 3.2 \\
\text { (Intention) }\end{array}$ & $\begin{array}{c}\text { Lesson Plan } 3.3 \\
\text { (Label) }\end{array}$ & $\begin{array}{c}\text { Lesson Plan } 3.4 \\
\text { (Procedure Text) }\end{array}$ \\
\hline $\begin{array}{l}\text { A topic for discussion, } \\
\text { which is related to the } \\
\text { achievement and } \\
\text { happiness that can foster } \\
\text { the behavior contained in } \\
\text { core competency. }\end{array}$ & $\begin{array}{l}\text { A topic for } \\
\text { discussion, which is } \\
\text { related to the actions } \\
\text { and student activities } \\
\text { at school, home, and } \\
\text { the surrounding } \\
\text { environment that can } \\
\text { foster the behavior } \\
\text { contained in core } \\
\text { competency. }\end{array}$ & $\begin{array}{l}\text { A topic for } \\
\text { discussion, which is } \\
\text { related to the } \\
\text { informations about } \\
\text { drugs, food, or } \\
\text { drinks that can } \\
\text { foster behavior is } \\
\text { contained in core } \\
\text { competency. }\end{array}$ & $\begin{array}{l}\text { A topic for discussion, } \\
\text { which is related to the } \\
\text { food or drink recipes, } \\
\text { equipment manuals } \\
\text { related to student life that } \\
\text { can foster the behavior } \\
\text { contained in core } \\
\text { competency. }\end{array}$ \\
\hline
\end{tabular}

Concerning the proposed learning materials, it appears that the teacher conducts learning materials for each lesson plan topic. In all topics, teachers focus on fostering the behavior contained in the core competencies. That is, teachers, link lesson plans with core competencies to make lesson plans appropriate for target students, which is very important for the successful implementation of lesson plans. RPP developed by considering the relevance and cohesiveness between competency standards, basic competencies, materials, teaching and learning activities, competency achievement indicators, assessments, and resources united in the learning experience (Darma et al., 2013; Evriana, 2020; Oktafianti, 2019). Guru memastikan bahwa rencana pelajaran yang dikembangkan relevan dan koheren antara komponen-komponen RPP ini seperti kompetensi skor, kompetensi dasar, materi, dan lain sebagainya serta mereka relevan dengan keragaman budaya.

The third step is to organize learning activities, namely activities designed or distributed by English teachers to realize or create learning conditions for learning. The teacher has fulfilled the pre 
activities, main activities, and post activities in online learning through Google Classroom. This means that the lesson plans made by the teacher meet the RPP aspects and can be implemented in online learning. The activities in the lesson plan consist of pre activities (initial activities in learning meetings that are shown to generate motivation and focus students' attention to actively participate in the learning process), main activities (a series of main actions in the learning process to achieve basic competencies), and post-work activities. (an activity carried out to end learning activities that can be carried out in the form of a summary or conclusion, assessment and reflection, feedback, and follow-up)(Abidah et al., 2019; Ali, 2018; Harahap et al., 2019; Susanto, 2016).

The fourth step is to choose learning media based on learning objectives. Learning media are tools in the form of physical and non-physical provided to deliver learning materials so that students can be more effective and efficient in the learning process. Thus, teaching materials can more quickly attract the attention, interest, and motivation of students. Furthermore, in choosing learning resources, English teachers must relate them to learning objectives. Learning resources are generally understood in the form of texts, videos, software, and other materials that help students meet learning expectations as defined in the curriculum (Artini \& Padmadewi, 2017; Megawati, 2016; Sidik et al., 2019; Surjono \& Susila, 2013). After determining learning resources based on learning objectives, the English teacher continues to select learning media and learning resources based on learning activities, and learning methods/techniques. Media and learning resources used by teachers can be seen in Table 3 .

Table 3. Media and learning resources used by teachers

\begin{tabular}{|c|c|c|c|}
\hline $\begin{array}{c}\text { Lesson Plan } 3.1 \\
\text { (Congratulation) } \\
\end{array}$ & $\begin{array}{c}\text { Lesson Plan } 3.2 \\
\text { (Intention) }\end{array}$ & $\begin{array}{c}\text { Lesson Plan } 3.3 \\
\text { (Label) }\end{array}$ & $\begin{array}{r}\text { Lesson Plan } 3.4 \\
\text { (Procedure Text) } \\
\end{array}$ \\
\hline $\begin{array}{l}\text { Learning Media: WhatsApp, } \\
\text { Google Classroom, Youtube }\end{array}$ & $\begin{array}{l}\text { Learning Media: } \\
\text { WhatsApp Group, } \\
\text { Google Classroom, } \\
\text { Video }\end{array}$ & $\begin{array}{l}\text { Learning } \\
\text { Media: } \\
\text { WhatsApp } \\
\text { Group, Google } \\
\text { Classroom, Video }\end{array}$ & $\begin{array}{l}\text { Learning Media: } \\
\text { WhatsApp Group, Google } \\
\text { Classroom, Video }\end{array}$ \\
\hline $\begin{array}{l}\text { Learning Resources: English } \\
\text { Book from Kemendikbud } \\
\text { (2017) }\end{array}$ & $\begin{array}{l}\text { Learning Resources: } \\
\text { English Book Think } \\
\text { Globally Act Locally } \\
\text { (2018) }\end{array}$ & $\begin{array}{l}\text { Learning } \\
\text { Resources: } \\
\text { English Book } \\
\text { Think Globally } \\
\text { Act Locally } \\
\text { (2018) }\end{array}$ & $\begin{array}{l}\text { Learning Resources: } \\
\text { English Book Think } \\
\text { Globally Act Locally (2018) }\end{array}$ \\
\hline
\end{tabular}

It can be seen that the teacher uses google classroom as one of the media in conducting the online teaching and learning process. In this case, the teacher uses google classroom to maximize students' potential in learning English. Google classroom is beneficial for both teachers and students and is a platform that can be applied as a medium for online learning, especially during this pandemic. Google classroom is effectively used, helping students to be able to learn even though they are far from the teacher.

The fifth step is to choose the type of assessment based on the learning objectives. Learning assessment is a method to measure how much knowledge and skills a learner has acquired in learning English. Aspects of the assessment carried out by the teacher in preparing the lesson plans can be seen in Table 4.

Table 4. Learning Assessment on Lesson Plans Made by Teachers

\begin{tabular}{|c|c|c|c|}
\hline $\begin{array}{c}\text { Lesson Plan 3.1 } \\
\text { (Congratulation) } \\
\end{array}$ & $\begin{array}{c}\text { Lesson Plan } 3.2 \\
\text { (Intention) }\end{array}$ & $\begin{array}{c}\text { Lesson Plan } 3.3 \\
\text { (Label) }\end{array}$ & $\begin{array}{c}\text { Lesson Plan } 3.4 \\
\text { (Procedure Text) }\end{array}$ \\
\hline Attitude: & Attitude: & Attitude: & Attitude: \\
\hline Responsible and disciplined & $\begin{array}{l}\text { Activeness and } \\
\text { cooperation of } \\
\text { students }\end{array}$ & $\begin{array}{l}\text { Activeness and } \\
\text { cooperation of } \\
\text { students }\end{array}$ & $\begin{array}{l}\text { Shows gratitude, } \\
\text { cooperation, discipline and } \\
\text { responsible }\end{array}$ \\
\hline Knowledge and Skills: & Knowledge and Skills: & Knowledge and & Knowledge and Skills: \\
\hline \multirow[t]{3}{*}{ Worksheet } & Fill in the blank test & Skills: & Answering questions \\
\hline & in the form of google & Worksheet & about procedure text \\
\hline & form & & $\begin{array}{l}\text { about a recipe for a dish or } \\
\text { drink, and Demonstrating } \\
\text { the making of food or } \\
\text { drink }\end{array}$ \\
\hline
\end{tabular}


From the assessment aspect, it can be seen that the teacher meets the attitude, knowledge, and skills in assessing students through online learning. By providing assessments, students can better understand and practice student skills. Through the assessment, the teacher will know the student's competence in mastering the lesson. Thus, giving assessments is an appropriate way to ask students to practice language so that they understand the language better (Abedi et al., 2004; Evriana, 2020; Maba, 2017).

\section{Conclusion}

The lesson plans developed can be applied in online learning because the teacher has completed the 2013 curriculum lesson plans, and uses google classroom as an appropriate platform for online learning. Suggestions that can be given are for teachers to develop lesson plans on other materials so that the online learning process can run optimally.

\section{References}

Abedi, J., Hofstetter, C. H., \& Lord, C. (2004). Assessment accommodations for english language learners: Implications for policy-based empirical research. Review of Educational Research, 74(1), 1-28. https://doi.org/10.3102/00346543074001001.

Abidah, A. F., Rukayah, R., \& Dewi, N. K. (2019). Sikap Kerjasama Melalui Permainan Bentengan Pada Anak Usia 5-6 Tahun. Jurnal Kumara Cendekia, https://doi.org/https://doi.org/10.20961/kc.v7i2.36332.

Alamsyah, S., Annisa, M., \& Kusnadi, D. (2018). Penerapan pendekatan keterampilan proses sains untuk meningkatkan hasil belajar IPA siswa kelas V-B SDN 045 Tarakan. LENSA (Lentera Sains): Jurnal Pendidikan IPA, 8(1), 11-18. https://doi.org/10.24929/lensa.v8i1.29.

Ali, L. U. (2018). Pengelolaan Pembelajaran IPA Ditinjau Dari Hakikat Sains Pada SMP Di Kabupaten Lombok Timur. Prisma Sains : Jurnal Pengkajian Ilmu Dan Pembelajaran Matematika Dan IPA IKIP Mataram, 6(2), 103. https://doi.org/10.33394/j-ps.v6i2.1020.

Antara, I. W. A., \& Renda, N. T. (2016). Analisis kesenjangan perencanaan dan pelaksanaan pembelajaran kurikulum 2013 di SD Negeri 4 Kaliuntu. Jurnal Pendidikan Dan Pengajaran, 49(2), 56. https://doi.org/10.23887/jppundiksha.v49i2.9010.

Artini, L. P., \& Padmadewi, N. N. (2017). Pelatihan Pembelajaran Inovatif Berbasis Karakter Berdasarkan Kurikulum 2013 Bagi Guru- Guru Bahasa Inggris Smp, Sma, Dan Smk Se Kabupaten Manggarai Barat. International Journal of Community Service Learning, 1(2), 104. https: //doi.org/10.23887/ijcsl.v1i2.12116.

Astria, W. J. (2013). The Implementation of Curriculum 2013 in Teaching English at SMPN 8 Padang. Journal Ilmiah Pendidikan Scholastic, 1, 33-41.

Bin-Hady, W. R. A., \& Abdulsafi, A. S. T. (2019). How Can I Prepare an Ideal Lesson-Plan? SSRN Electronic Journal, 7(4). https://doi.org/https://doi.org/10.2139/ssrn.3434031.

Damsik, M. G. (2017). Penerapan Supervisi Klinis untuk Perbaikan Kegiatan Belajar Mengajar di Madrasah Aliyah Paradigma Palembang. Conciencia, 17(2), 46-57.

Darma, S. D., Suwarno, B., \& Mulyadi, M. (2013). English Teachers' Difficulties in Designing Lesson Plan based on KTSP (A study on English Teachers at Vocational High Schools in Bengkulu City). Journal of Chemical Information and Modeling, 53(9), 1689-1699.

Evriana, L. (2020). The Implementation of Online Assessment in English Lesson at 10th Grade Student of SMA Nasional 3 Bahasa Putera Harapan. State Institute of Islamic Studies Purwokerto.

Fauziah, U. N. El, Suryani, L., \& Syahrizal, T. (2019). Penerapan Google Classroom Dalam Pembelajaran Bahasa Inggris Kepada Guru-Guru Bahasa Inggris Smp Di Subang. Abdimas Siliwangi, 2(2), 183. https://doi.org/10.22460/as.v2i2p183-191.3281.

Fitriyanti, A. N. (2019). The Problems Faced by English Teachers in Making Lesson Plan. Makassar Muhammadiyah University.

Harahap, H. N., Priatna, O. S., \& Nawawi, K. (2019). Meningkatkan hasil belajar IPS dengan model pembelajaran talking stick pada siswa kelas IV MI Nurul Huda 1 Curug. Jurnal PGSD Jurnal $\begin{array}{llll}\text { Pendidikan Guru } & \text { Sekoah } & \text { Dasar, } & \text { 79-92), }\end{array}$ https: //ejournal.unib.ac.id/index.php/pgsd/article/view/8054/pdf.

Istiqomah, F. (2018). Analisis Kemampuan Menyusun RPP Kurikulum 2013 pada Mahasiswa Pendidikan Kimia FKIP Universitas Tanjungpura. Universitas Tanjungpura.

Kurniawati, M., Santanapurba, H., \& Kusumawati, E. (2019). Penerapan Blended Learning Menggunakan Model Flipped Classroom Berbantuan Google Classroom Dalam Pembelajaran Matematika SMP. 
EDU-MAT: Jurnal Pendidikan $\quad$ Matematika, $\quad 7(1), \quad$ 8-19. https: //doi.org/10.20527/edumat.v7i1.6827.

Maba, W. (2017). Teachers' Perception on the Implementation of the Assessment Process in 2013 Curriculum. International Journal of Social Sciences and Humanities, 1(2), 1-9.

Megawati, F. (2016). Kesulitan Mahasiswa Dalam Mencapai Pembelajaran Bahasa Inggris Secara Efektif. Jurnal Pedagogia, 5(2). http://ojs.umsida.ac.id/index.php/pedagogia/article/view/246/227.

Oktafianti, T. (2019). An Analysis of Lesson Plan made by an English Teacher referring to Curriculum 2013 at MTS Al-Qur'an Harsallakum Bengkulu in Academic Year 2018/2019. State Institute for Islamic Studies (IAIN) Bengkulu.

Rahardjo, M. M. (2016). Menciptakan High Level of Play Dalam Rencana Pembelajaran Anak Usia Dini. Scholaria: Jurnal Pendidikan Kan https://doi.org/10.24246/j.scholaria.2016.v6.i3.p206-216.

Sidik, A. S., Keguruan, F., \& Huda, U. Q. (2019). Improving Reading Comprehension of The Second Grade Students by Using Graphic Organizer. JPE (Jurnal Pendidikan Edutama), 6(2), 47-52. https://doi.org/http://dx.doi.org/10.30734/jpe.v6i2.523.

Suciati, R., \& Astuti, Y. (2019). Analisis Rencana Pelaksanaan Pembelajaran (Rpp) Mahasiswa Calon Guru Biologi. Edusains, 8(2), 192-200. https://doi.org/10.15408/es.v8i2.4059.

Sulistyowati, Y. (2014). Pengembangan Perangkat Pembelajaran Bangun Ruang di SMP dengan Pendekatan Creative Problem Solving. Pythagoras: Jurnal Pendidikan Matematika, 9(2), 219-232. https://doi.org/10.21831/pg.v9i2.9082.

Surjono, H. D., \& Susila, H. R. (2013). Pengembangan multimedia pembelajaran bahasa inggris untuk SMK. Jurnal Pendidikan Vokasi, 3(1), 45-52. https://doi.org/10.21831/jpv.v3i1.1576.

Susanto, J. (2016). Pengembangan Perangkat Pembelajaran Berbasis Lesson Study Dengan Kooperatif Tipe Numbered Heads Together Untuk Meningkatkan Aktivitas Dan Hasil Belajar Ipa Di Sd. Journal of Primary Educational, 1(7). https://doi.org/http://dx.doi.org/10.17977/jp.v1i7.6589.

Wicaksono, M. D. (2020). Pemanfaatan Google Classroom Dalam Strategi Pembelajaran Kooperatif pada Mata Pelajaran IPS Kelas VIII. Jurnal Ilmu Ilmu Sosial, 17(1), 234-242. https://doi.org/https://doi.org/10.29100/insp.v17i1.1568. 